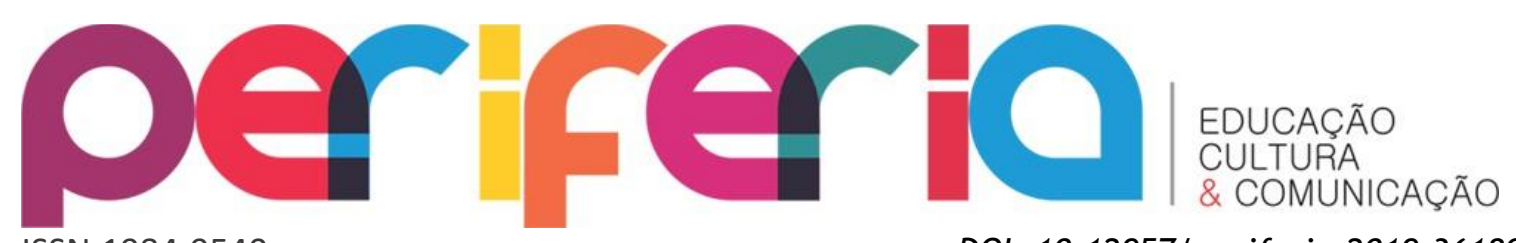

ISSN:1984-9540

DOI: $10.12957 /$ periferia.2019.36180

\title{
ENSINAR-APRENDER COM OS MEMES: QUANDO AS ESTRATÉGIAS DE SUBVERSÃO E RESISTÊNCIA VIRALIZAM NA INTERNET
}

\author{
Dilton Ribeiro Couto Junior ${ }^{1}$ \\ Universidade do Estado do Rio de Janeiro \\ Fernando Pocahy ${ }^{2}$ \\ Universidade do Estado do Rio de Janeiro \\ Felipe da Silva Ponte de Carvalho 3 \\ Universidade do Estado do Rio de Janeiro
}

\section{Resumo}

Este texto explora a forma como os memes podem constituir-se enquanto potentes estratégias contemporâneas de subversão e resistência às normas que regulam/governam corpos, gêneros e sexualidades. A infraestrutura técnica do ciberespaço possibilita que uma quantidade significativa de usuárias/os hoje possa (co)criar, "curtir" e compartilhar amplamente informações dos mais variados tipos (imagens, vídeos, sons etc) para outras pessoas geograficamente dispersas. Muitas dessas informações desenvolvidas colaborativamente evidenciam a força política dos usos feitos das redes sociais online na criação de estratégias de resistência direcionadas no combate ao regime (cis)heterocentrado, responsável pela desqualificação de corpos, gêneros e sexualidades dissidentes, comumente designados de anormais e estranhos. Se por um lado as redes sociais online caracterizam-se enquanto um terreno fértil para a viralização de discursos preconceituosos/discriminatórios, por outro lado é através dessas mesmas redes que muitos usuários vêm encontrando brechas e formulando caminhos no combate às mais perversas formas de desqualificação de determinados grupos sociais de sujeitos que integram as chamadas "minorias" sexuais, de gênero e étnico-raciais. 0 trabalho apresenta algumas dessas experimentações nos/com os cotidianos, acompanhando analiticamente seus modos de produção e algo daquilo que pode se constituir como enunciações coletivas.

Palavras-chave: redes sociais online, "minorias" sociais, memes, educação.

\footnotetext{
${ }^{1}$ Doutor pelo Programa de Pós-Graduação em Educação da Universidade do Estado do Rio de Janeiro (ProPEd/UERJ). Pós-doutorando (bolsista PNPD/CAPES) no Programa de Pós-Graduação em Educação, Cultura e Comunicação em Periferias Urbanas (PPGECC) da UERJ/FEBF. Membro do Grupo de Pesquisa Infância, Juventude, Educação e Cultura (IJEC) e do Grupo de Estudos em Gênero e Sexualidade e(m) Interseccionalidades (Geni). E-mail:junnior_2003@yahoo.com.br

2 Professor da Faculdade de Educação e do Programa de Pós-Graduação em Educação da Universidade do Estado do Rio de Janeiro (ProPEd/UERJ). Líder do Grupo de Estudos em Gênero e Sexualidade e(m) Interseccionalidades (Geni).

${ }^{3}$ Doutorando (bolsista FAPERJ) no Programa de Pós-Graduação em Educação da Universidade do Estado do Rio de Janeiro (ProPEd/UERJ). Membro do Grupo de Estudos em Gênero e Sexualidade e(m) Interseccionalidades (Geni).
} 


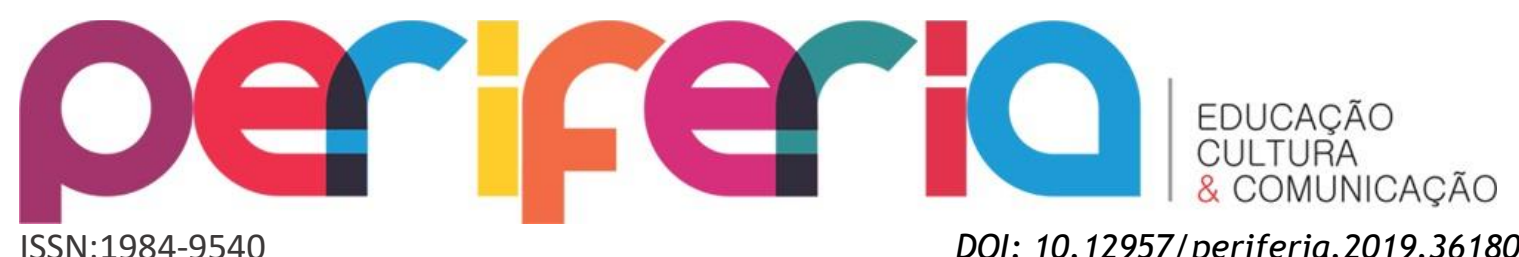

TEACHING AND LEARNING WITH MEMES: WHEN SUBVERSION AND
RESISTANCE STRATEGIES VIRALIZE ON THE INTERNET

\begin{abstract}
This article shows that memes can be powerful contemporary strategies of subversion and resistance to (hetero)norms that regulate/govern bodies, genders and sexualities. The technical infrastructure of cyberspace enables a significant number of users to (co)create, "like" and share information of all kinds (images, videos, sounds, links, etc) to geographically dispersed people. Much of this information developed collaboratively evidences the political power to combat (hetero)norms, responsible for the disqualification of bodies, gender and sexualities commonly designated as abnormal and strange. On the one hand, online social networks are a means for the viralization of prejudiced/discriminatory discourses, on the other hand, through these same networks that many users are finding ways to combat the most perverse forms of disqualification of certain social groups, so-called "minorities" (ethnic-racial, gender and sexual minorities). The work presents some of these experiments in/with the daily quotidian, accompanying analytically its modes of production and something of what can be constituted as collective statements.
\end{abstract}

Keywords: online social networks, social "minorities", memes, education. 


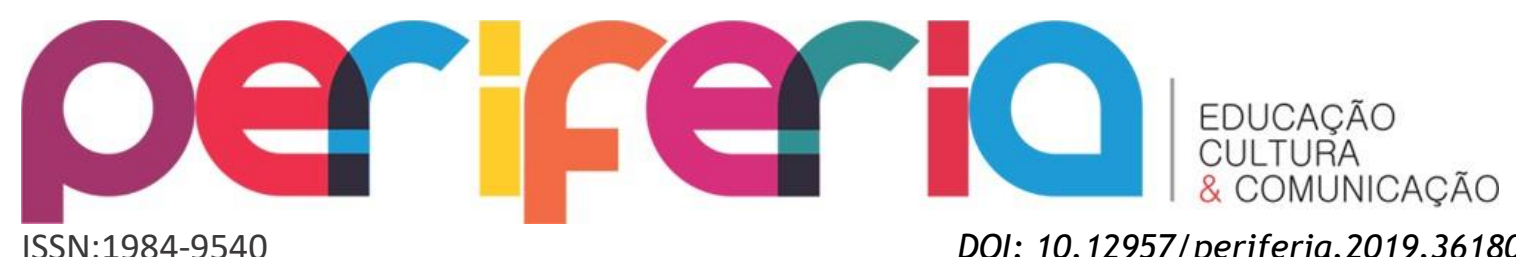

\section{ENSEÑAR-APRENDER CON MEMES: CUANDO LAS ESTRATEGIAS DE SUBVERSIÓN Y RESISTÊNCIA VIRALIZAN EN INTERNET}

\section{Resumen}

Este texto explora la forma como los memes pueden constituirse como potentes estrategias contemporáneas de subversión y resistencia a las normas que regulan/gobiernan cuerpos, géneros y sexualidades. La infraestructura técnica del ciberespacio posibilita que una cuantidad significativa de usuarias/os hoy pueda (co)crear, "me gusta" y compartir ampliamente información de los más variados tipos (imágenes, videos, sonidos etc) para otras personas geográficamente dispersas. Muchas de estas informaciones desarrolladas colaborativamente evidencian a la fuerza política de los usos hechos de las redes sociales en línea en la creación de las estrategias de resistencia direccionadas en el combate al régimen (cis)heterocentrado, responsable por la descualificación de los cuerpos, géneros y sexualidades disidentes, comúnmente designados de anormales y extraños. Si por un lado las redes sociales en línea se caracterizan como un terreno fértil para la viralización de discursos preconceptos/discriminatorios, por otro lado es a través de esas mismas redes que muchos usuarios vienen encontrando brechas y formulando caminos en el combate a las más perversas formas de descualificación de determinados grupos sociales de sujetos que integran las llamadas "minorías" sexuales, de género y étnico-raciales. El trabajo presenta algunas de esas experimentaciones en/con los cotidianos, acompañando analíticamente sus modos de producción y algo de aquello que puede constituirse como enunciaciones colectivas.

Palabras-clave: redes sociales online, "minorías" sociales, memes, educación. 


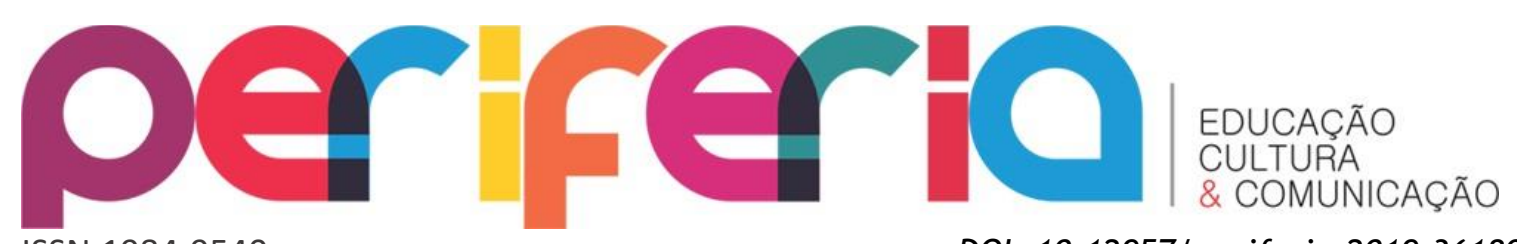

ISSN:1984-9540

DOI: $10.12957 /$ periferia.2019.36180

\section{Viralizando imagens/ideias através das redes sociais da internet: iniciando o debate}

Produzir informação e conhecimento passa a ser, portanto, a condição para transformar a atual ordem social. Produzir de forma descentralizada e de maneira não-formatada ou preconcebida. Produzir e ocupar os espaços, todos os espaços, através das redes. Nesse contexto, a apropriação da cultura digital passa a ser fundamental, uma vez que ela já indica intrinsecamente um processo crescente de reorganização das relações sociais mediadas pelas tecnologias digitais, afetando em maior ou menor escala todos os aspectos da ação humana ${ }^{4}$.

Nelson Pretto e Alessandra Assis

A emergência dos dispositivos móveis com acesso à internet (aparelhos telefônicos do tipo smartphone, tablets etc) vêm permitindo às/aos usuárias/os usufruir de uma gigantesca rede de dados a qualquer hora e em praticamente qualquer lugar, favorecendo o intercâmbio de experiências sociais mediadas pelas tecnologias digitais em rede (SANTAELLA, 2013). Não mais permanecemos somente na posição de meras/os receptoras/es de informações, pois com as possibilidades sócio-técnicas da internet hoje temos a chance de produzir e compartilhar variados tipos de arquivos (imagens, vídeos, sons etc) com outras pessoas geograficamente dispersas (LEMOS; LÉVY, 2010). O consumo cultural das mídias de massa não permite aos sujeitos interferir/modificar o conteúdo da mensagem, no entanto, a popularização do digital em rede vem abrindo amplas possibilidades para que possamos experimentar uma dinamicidade comunicacional que prevê a interação com outras/os internautas para além da palavra escrita. Em uma perspectiva cotidianista, os praticantes culturais apropriam-se dessas produções digitais ativamente, com a cibercultura oportunizando a (co)criação colaborativa entre sujeitos, fazendo com que as ideias sejam "debatidas, confrontadas, tecidas e aprimoradas, com vistas a ir além da condição de consumidor de conteúdos, passando também a criar, disponibilizar, discutir e compartilhar suas autorias em rede" (SANTOS; CARVALHO, 2018, p. 34).

\footnotetext{
${ }^{4}$ PRETTO; ASSIS, 2008, p. 78.
} 


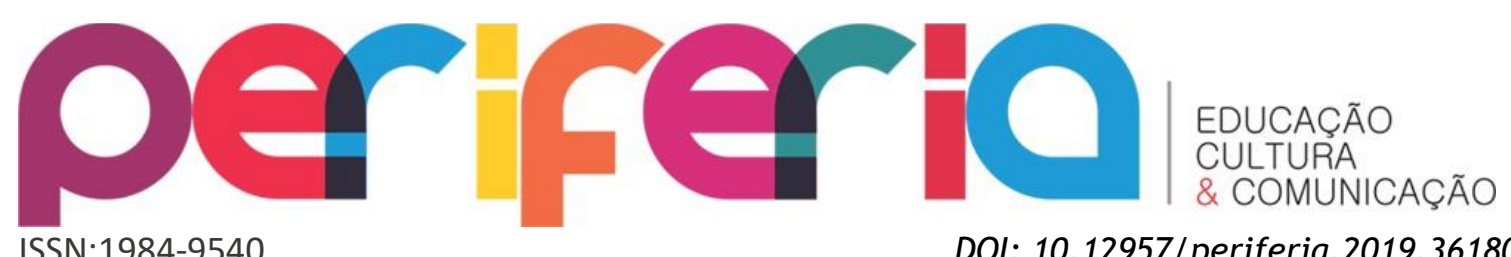

As experiências sociais contemporâneas, principalmente daquelas pessoas que se movimentam pelos grandes centros urbanos, são constituídas da presença abundante de imagens. Diariamente interagimos "com grandes outdoors, pinturas, desenhos, imagens capturadas pelas lentes das câmeras fotográficas digitais e dos smartphones, imagens em movimento produzidas pela indústria cinematográfica, além de inúmeras outras" (COUTO JUNIOR, 2015, p. 40, grifos do autor). 0 acesso à internet somado ao custo cada vez mais baixo dos equipamentos digitais permitem que a produção e o compartilhamento de imagens deixassem de ser restritos às grandes empresas e passassem a ser mais popularizados (PRETTO, 2013). Com a emergência das redes sociais online como Facebook e Instagram, a proliferação de imagens digitais constitui hoje parte do cenário das práticas sociais mediadas pelo digital. As imagens produzidas e compartilhadas revelam "expressões particulares, comunicam intencionalidade, são testemunhas de mudanças ocorridas, indicam compreensão e visões de mundo, registram momentos que ficam na memória como os antigos álbuns de família. Elas circulam contando e recontando histórias" (SANTOS; COLACIQUE; CARVALHO, 2016, p. 136). Afinal, por que (m) as histórias são (re)contadas e compartilhadas na rede?

Enquanto educadoras/es, cabe colocarmos em debate os efeitos discursivos de imagens digitais que vêm se proliferando através das redes online e que são responsáveis pela desqualificação de corpos, gêneros e sexualidades comumente designados de anormais e estranhos. Cabe desconstruirmos esses enunciados discursivos veiculados pelas imagens-memes na tentativa de produzir pedagogias que sejam capazes de colocar em prática o argumento central de que todos os corpos importam - e isso significa tornar visível as experiências sociais daquelas pessoas colocadas na condição de seres abjetos com o objetivo de nos posicionarmos “político e eticamente na celebração dos modos periféricos de ser e viver" (COUTO JUNIOR; SILVA, 2018, p. 33). O sujeito abjeto também é designado como sendo aquela pessoa cujo corpo “'improdutivo', 'precário’, 'bizarro’, 'monstruoso' e 'desqualificado'” (POCAHY, 2012a, p. 370) apresenta inúmeros desafios em todas as esferas da sociedade para ocupar um lugar social digno de ser-viver. Não somos ingênuas/os ao acreditar que a "culpa" do aumento de toda violência de gênero ou 


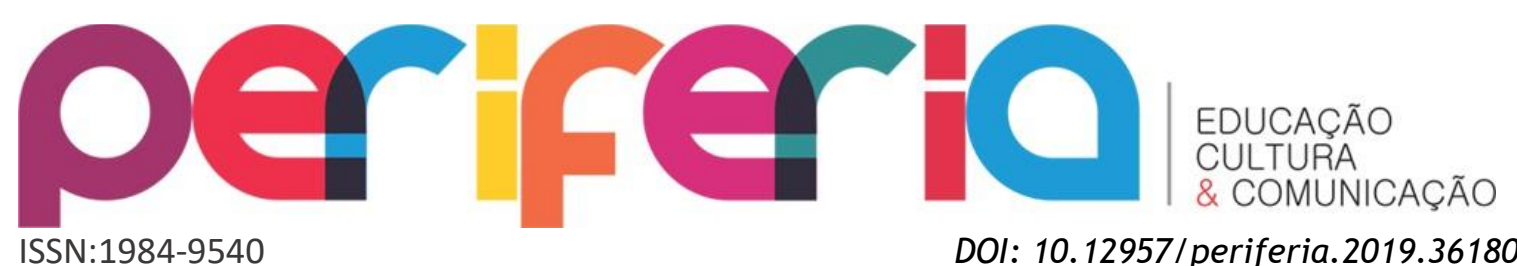

de qualquer forma de preconceito e discriminação seja das redes sociais da internet. As redes são constituídas por pessoas de carne e osso que pensam, escrevem, opinam e participam ativamente de discussões envolvendo inúmeras questões sociais. Por detrás de cada comentário "raivoso" envolvendo questões racistas, misóginas, gordofóbicas e LGBTfóbicas existe uma pessoa que está produzindo e compartilhando ideias por meio do uso de algum artefato cultural com acesso à internet. Dito isso, se por um lado as redes sociais da internet podem ser consideradas enquanto um terreno fértil para a viralização de discursos preconceituosos/discriminatórios (RECUERO, 2013), por outro lado é através dessas mesmas redes que muitos usuários vêm encontrando brechas e formulando caminhos no combate às mais perversas formas de desqualificação de determinados grupos de sujeitos que integram as chamadas "minorias" sexuais, de gênero e étnico-raciais (COUTO JUNIOR; OSWALD, 2017).

Dentro do contexto acima mencionado, o presente texto busca lançar um olhar atento e crítico para os arquivos imagéticos produzidos e compartilhados pelas/os usuárias/os na Web, buscando refletir sobre a forma como os memes podem constituir-se enquanto potentes estratégias contemporâneas de subversão e resistência às normas regulatórias de gênero. Com esse texto assumimos o compromisso ético de nos engajarmos "no enfrentamento ao heterossexismo, ao racismo e outras formas arbitrárias e hierarquias sociais" (POCAHY, 2016, p. 292). Reconhecemos a força política das redes sociais online na criação de estratégias de subversão e resistência direcionadas no combate ao regime (cis)heterocentrado ${ }^{5}$, com muitos memes auxiliando na promoção de práticas desconstrucionistas intermediadas pelo humor.

No contexto político contemporâneo, precisamos reconhecer "a força dos movimentos espontâneos em rede, cujos efeitos antes não eram possíveis em uma sociedade caracterizada pela mídia de massa. As próprias práticas de ciberativismo

\footnotetext{
${ }^{5}$ Regime heterocentrado é expressão cunhada por Preciado (2014) para designar a ordem social vigente, amparada pela supremacia de práticas hegemônicas alinhadas com a naturalização e normatização da relação monogâmica homem-mulher com fins reprodutivos. Adicionamos o termo "cis" (referente à cisgênero) à expressão "regime heterocentrado" para dar ênfase também às pessoas que se identificam e aquelas que não se identificam com os gêneros que lhes foram atribuídos no nascimento.
} 


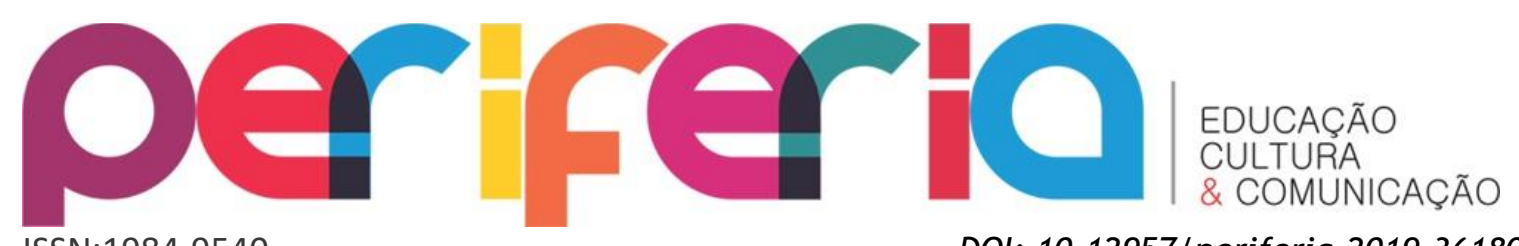

ISSN:1984-9540

DOI: $10.12957 /$ periferia.2019.36180

comprovam a força dos meios digitais para a articulação, mobilização e ações políticas" (PRIMO, 2013, p. 17). Acreditamos que essas práticas sociais mediadas pelas redes online potencializam a construção de novas perspectivas de vida que sejam promotoras de profundos questionamentos em torno das formas com as quais corpos, gêneros e sexualidades vêm sendo governados pelo regime (cis)heterocentrado. Esse regime busca manter intacta a supremacia das (cishetero)normas ao operar incessantemente com a tentativa de "inscrever corpos, gêneros e sexualidades dentro de modelos binários, restritos e universalizantes" (COUTO JUNIOR; OSWALD; POCAHY, 2018, p. 134). Na tentativa de apontar as fragilidades e contingências das (cis)heteronormas, colocando em xeque o pensamento hegemônico que opera através da desqualificação de todos os corpos que se distanciam das convenções culturais hegemônicas, as/os internautas da era digital, ao engajarem-se em mobilizações políticas mediadas pelas redes sociais online, têm o potencial de se tornarem "capazes de inventar novos programas para suas vidas com as matérias-primas de seu sofrimento, suas lágrimas, seus sonhos e esperanças" (CASTELLS, 2013, p. 14).

Sujeitos colocados constantemente na mira dos olhares (cishetero)normativos organizam-se em comunidades online dedicadas ao fortalecimento de suas/seus integrantes, buscando implicarem-se em questões sociais voltadas para a luta contra o preconceito e a discriminação (COUTO JUNIOR; OSWALD, 2017). Os memes apresentados e discutidos neste texto evidenciam "imageticamente aspectos da realidade, trazem em seu viés cômico elementos para que a imaginação recrie/reinterprete a realidade por ele representada" (SANTOS; COLACIQUE; CARVALHO, 2016, p. 138). Diante do exposto, como os memes da internet auxiliam na construção de estratégias de subversão e resistência às (cishetero)normas que regulam/governam corpos, gêneros e sexualidades? Como os memes nos convidam a pensar sob novos pontos de vista os acontecimentos sociais, virando de ponta a cabeça a ordem vigente que desqualifica determinados grupos de sujeitos? Nossa intenção com esse texto é fomentar reflexões que sejam convidativas no questionamento às diferentes "formas de dominação e hierarquização social, acionando argumentos políticos, sociais e culturais que se articulam na definição da 


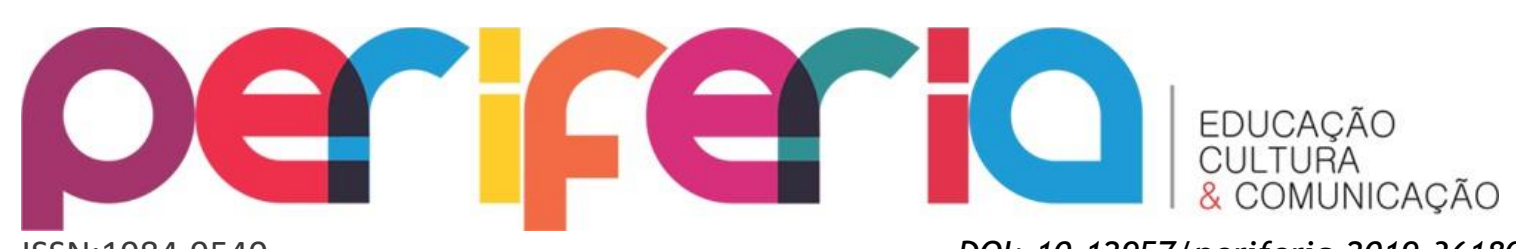

ISSN:1984-9540

DOI: $10.12957 /$ periferia.2019.36180

episteme do mundo - na definição complexa das relações saber-poder" (POCAHY, 2011, p. 20, grifo do autor).

\section{Memes: definição e breve panorama histórico}

Passei por uns meninos que jogavam bola, e eles: "Olha lá aquela mulher dos memes". Tô com 50 anos de carreira, trabalhei a vida toda para virar a "mulher dos memes".

Renata Sorrah

O termo meme foi cunhado pelo zoólogo Richard Dawkins ao fazer uma comparação entre meme e gene na obra de sua autoria O Gene Egoísta (1976). Torres (2016, p. 60) mostra que, na visão de Dawkins, meme seria a repetição de hábitos e costumes no contexto de "uma determinada cultura. Adaptado para a internet, especialmente para as redes sociais, o conceito de meme passa a ser uma 'unidade' propagada ou transmitida através da repetição e imitação, de usuário para usuário ou de grupo para grupo". Os termos viralização/viral, emprestados do campo biológico, também foram res-significados no contexto da cibercultura, remetendo tudo àquilo que se espalha rapidamente através da internet (TORRES, 2016). A infraestrutura técnica da rede é bastante promissora para que os memes sejam compartilhados rapidamente pelas/os internautas através das redes sociais online.

Nossa intenção aqui não é discutir o valor sociocultural dos memes no contexto brasileiro. Nos interessa perceber o fato de que mesmo a atriz Renata Sorrah tendo investido 50 anos em sua carreira, ser reconhecida na rua como a "mulher dos memes" indica o quanto as práticas sociais mediadas pelo digital em rede vêm reconfigurando os processos de interação com o outro na vida cotidiana. Interagir com as informações que circulam nas redes online é um verdadeiro convite para o que outras/os usuários/as têm a (re)contar, com os memes apresentando "muitas

\footnotetext{
${ }^{6}$ Para maiores informações sobre o depoimento da atriz, além de memes que foram elaborados e inspirados na personagem Nazareth Tedesco interpretado por ela, acesse o seguinte link: <https://bit.ly/2ANYlUD>. Acesso em: 13 abr. 2018.
} 


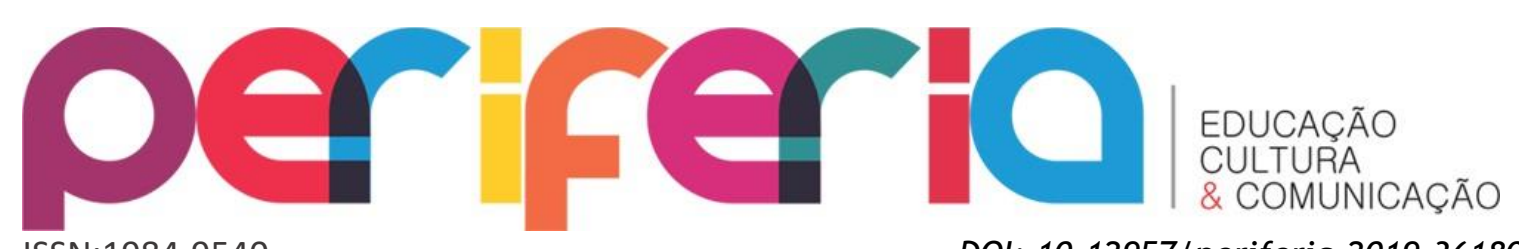

ISSN:1984-9540

formas de intertextos, dialogando permanentemente com a realidade tanto 'dentro' da internet, quanto 'fora' dela"7 (SANTOS; COLACIQUE; CARVALHO, 2016, p. 154).

0 que conhecemos como meme da internet hoje surgiu no final da década de 1990 (TORRES, 2016). Ainda que seja bastante recente a emergência dos memes no contexto das redes sociais online, trabalhos de diversas áreas do conhecimento vêm centralizando seus esforços investigativos em torno da análise dos memes nas experiências comunicacionais das/os internautas. Neste contexto, vale destacar estudos que já se dedicaram a: a) investigar os usos dos memes na criação publicitária (SILVA; TOMÉ; SILVA, 2013); b) discutir a criação de uma tipologia inicial dos gêneros mais recorrentes na memesfera brasileira (OLIVEIRA NETA, 2017); c) pesquisar os usos dos memes na comunicação mediada por computadores nas redes sociais online (SANTOS; COLACIQUE; CARVALHO, 2016; VOLCAN, 2014), incluindo esses usos em práticas sociais online contra questões relacionadas à desigualdade de gênero (PIÑEIRO-OTERO; MARTÍNEZ-ROLÁN, 2016) e; d) fornecer um panorama da produção acadêmica brasileira que focalizou a análise dos memes na comunicação online (DIAS et alii, 2015).

Os memes geralmente são constituídos com base em uma linguagem informal e humorística, comumente viralizando informações produzidas por suas/seus autoras/es (VOLCAN, 2014). Promovendo o fortalecimento dos vínculos sociais e afetivos, os "memes funcionam como modos de sentir coletivos que geram, principalmente, humores e afetividades" (OLIVEIRA NETA, 2017, s/p, grifos da autora). Investigar os usos dos memes nas dinâmicas comunicacionais na/da internet é um convite para que possamos colocar em prática "processos de leitura dessas imagens envolvem concepções estéticas, ideológicas, culturais, nossos conhecimentos, modos de ver e compreender o mundo" (SANTOS; COLACIQUE; CARVALHO, 2016, p. 142-143). Frente a isso, cabe refletirmos sobre as possibilidades comunicacionais que emergem com o uso dos memes nas dinâmicas interativos entre usuárias/os geograficamente dispersas/os.

\footnotetext{
7 Sobre o "dentro" e "fora" da rede, vivemos em uma época em que é cada vez mais difícil separar online e offline porque as práticas sociais mediadas pelas tecnologias digitais em rede - e que são potencializadas pelos processos comunicacionais móveis - tornam os espaços físicos e eletrônicos indissociáveis (COUTO JUNIOR; OSWALD, 2014).
} 


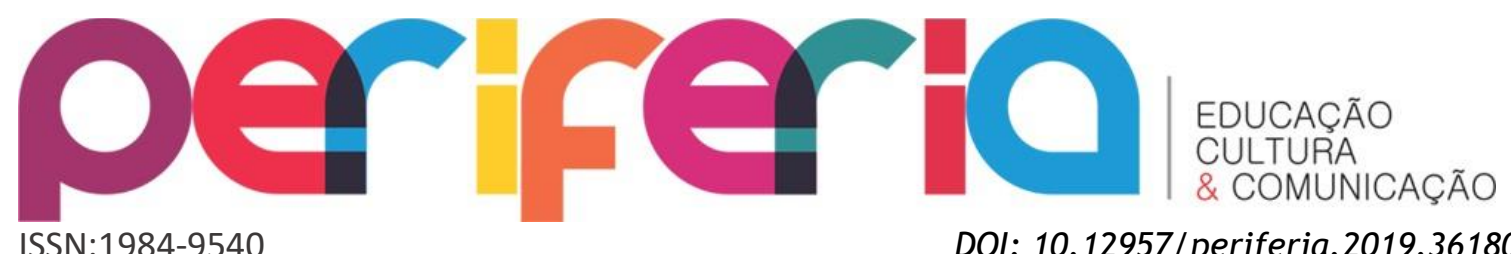

Um dos casos mais notórios de viralização de memes no Brasil é o da personagem Nazaré Tedesco na novela Senhora do Destino (2004-2005). Interpretada pela atriz Renata Sorrah, imagens de Nazaré foram e vêm sendo ainda muito utilizadas para a confecção de memes, revelando o potencial criativo e humorístico das/os usuárias/os brasileiras/os (figura 1). Tamanha popularidade da personagem fez com que as/os usuárias/os criassem diversas páginas em redes sociais como o Facebook dedicadas à elaboração e ao compartilhamento de memes de Nazaré. Uma dessas páginas é a "Nazareth - a orientadora", com mais de 100 mil seguidoras/es, e que apresenta "Uma dose de humor para aqueles que fazem pesquisa! Sou Professora, Doutora, Pós Doutora, Pós-Pós Doutora e tenho vagas abertas para orientar TCC, M.A e Ph.D"8. A página revela a (re)apropriação da vilã da telenovela no campo acadêmico, evidenciando o quanto os memes produzidos e compartilhados na comunidade produz uma forma de pedagogia que coloca em prática um certo modo de conduzir o trabalho das/os estudantes.

0 aspecto viral dos memes evidencia o processo colaborativo das/os usuárias/os na (re)criação de legendas e (re)edição de imagens (figura 2). Caminhando com esse pensamento, não há como negar que devido ao "caráter 'amador' em termos de recursos tecnológicos envolvidos em sua produção, os memes viabilizam a autoria dos/as usuários/as da internet, que podem, eles próprios, criar e compartilhar sua versão do meme" (SANTOS; COLACIQUE; CARVALHO, 2016, p. 154).

\footnotetext{
${ }^{8}$ Informação disponível em: <https://bit.ly/2NVm1y1>. Acesso em: 16 jul. 2018.
} 


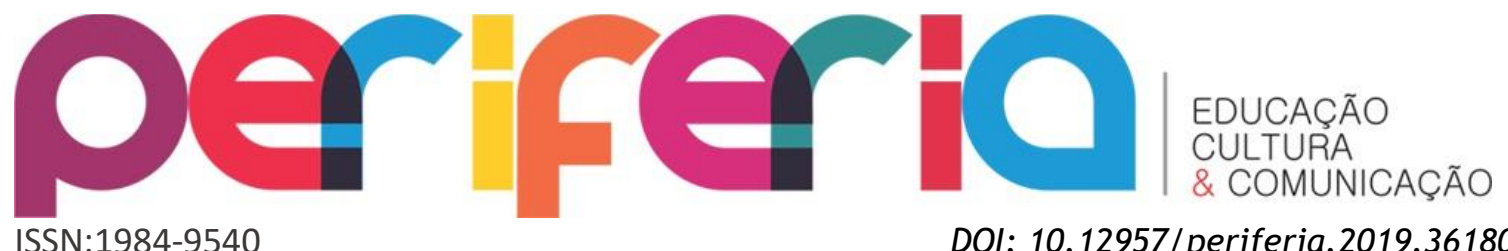

Imagem 1 - Nazaré Tedesco, a rainha dos memes
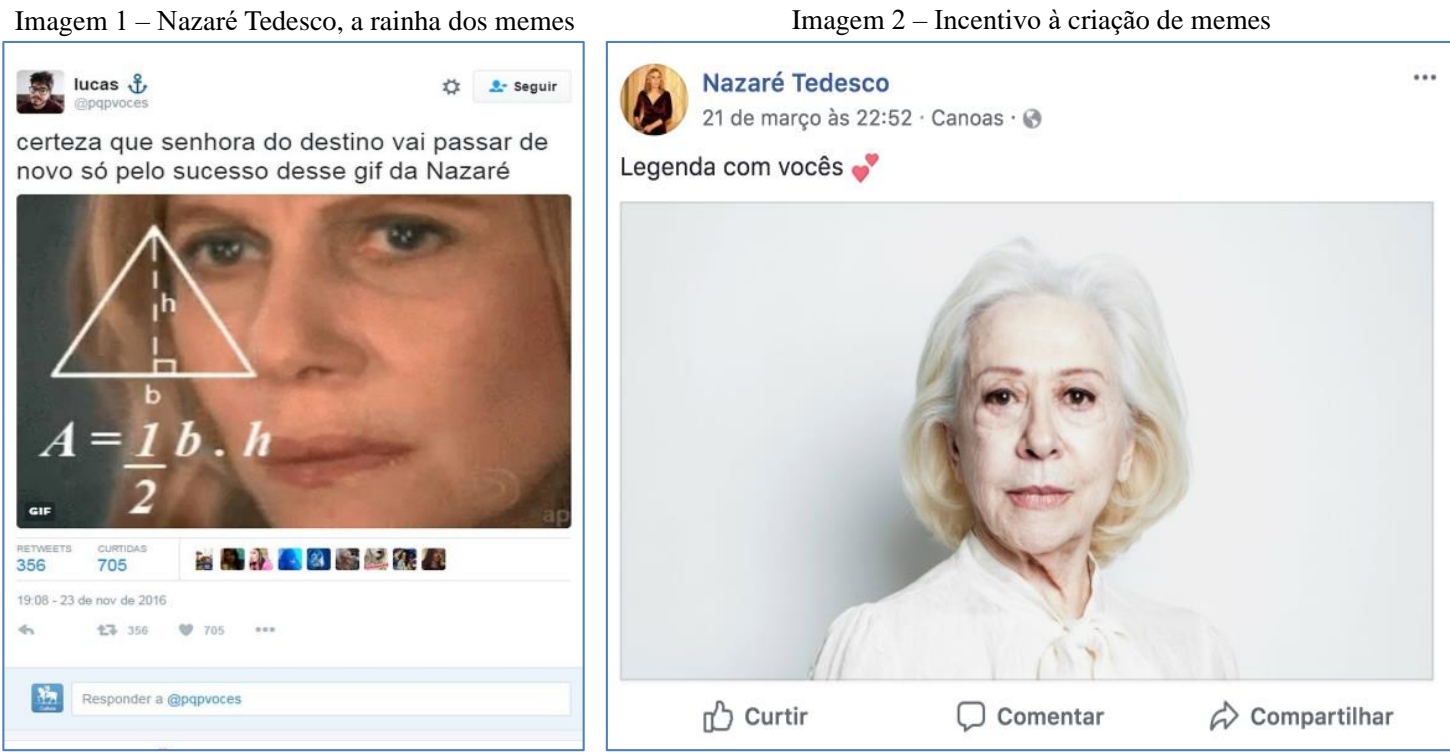

Fonte da imagem 1: Estadão / <goo.gl/iXweMZ>

Fonte da imagem 2: Facebook / <https://www.facebook.com/OficialNazareTedesco/>

A Universidade Federal Fluminense (UFF), instituição localizada no Estado do Rio de Janeiro, vem desenvolvendo o projeto \#MUSEUdeMEMES no curso de Estudos de Mídia. 0 museu de memes (figura 3), fruto deste projeto, foi criado em 2015 com a intenção de preservar a memesfera brasileira. 0 webmuseu, o primeiro deste tipo no país focalizado no acervo imagético de memes, é constituído de uma ampla e rica produção cultural visual, de referências bibliográficas (livros, artigos etc) importantes para uma melhor compreensão/leitura de mundo do fenômeno dos memes, além de ofertar propostas educativas que incentivam as atividades de pesquisa e extensão ligadas à universidade fluminense ${ }^{9}$.

\footnotetext{
${ }^{9}$ Para maiores informações dessas e outras atividades, acesse o webmuseu, disponível no seguinte link: <http://www. museudememes.com.br/>. Acesso em: 17 abr. 2018.
} 


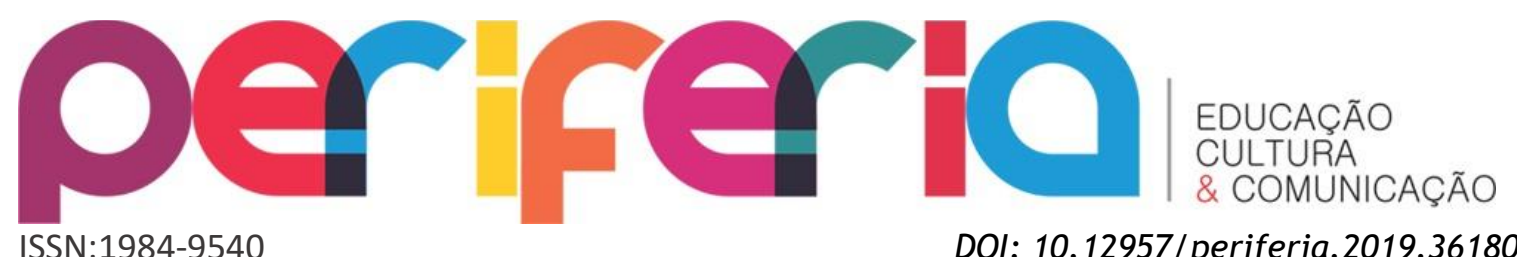

DOI: $10.12957 /$ periferia.2019.36180

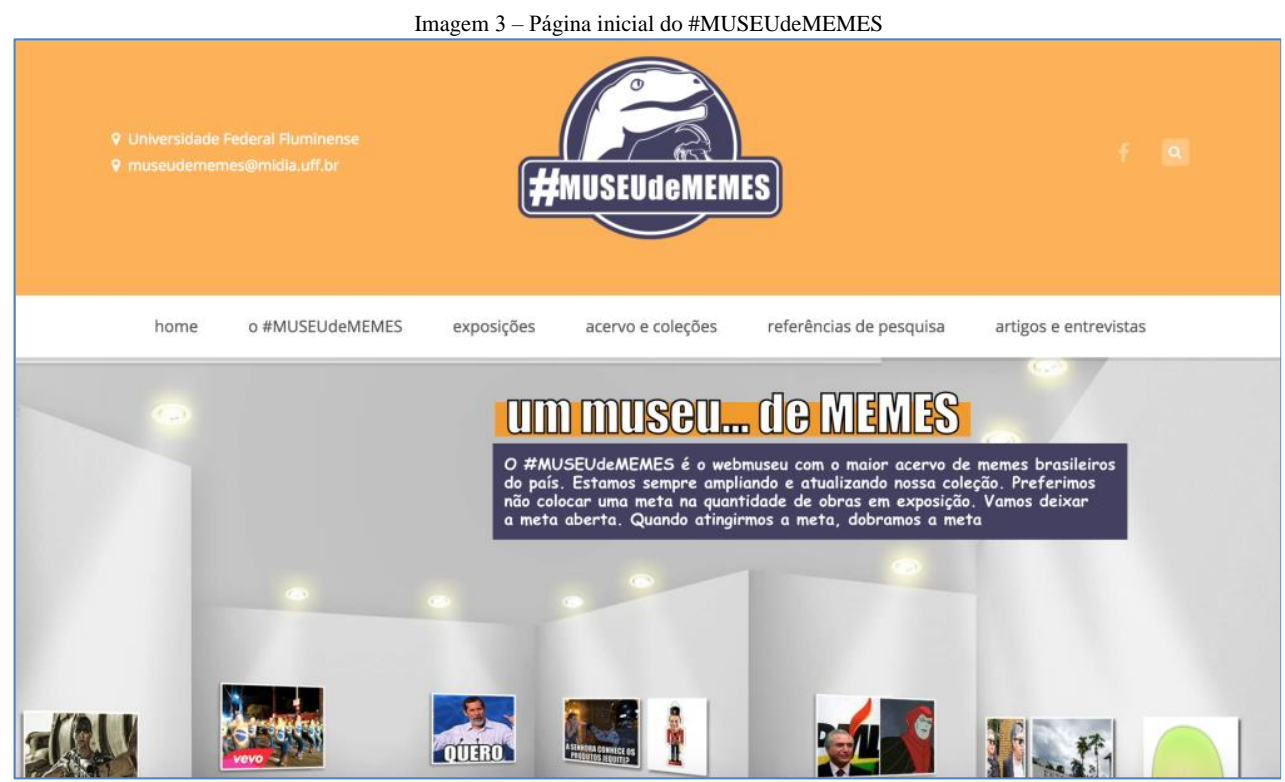

Fonte da imagem 3: \#MUSEUdeMEMES / <http://www.museudememes.com.br/>

Essa estreita relação do museu com atividades de pesquisa e extensão revelam o quão fecundas são as possibilidades de ensinar-aprender que emergem dos usos dos memes nos processos interativos/afetivos/comunicacionais das/os usuárias/os. Os memes vêm modificando nossa relação com o mundo, afetando significativamente a constituição dos processos de subjetivação das/os usuários de redes sociais. A forma como vimos utilizando as tecnologias digitais estão favorecendo a construção de novas estratégias de interação com outras pessoas e, com isso, promovendo "um certo modo de ver as coisas, interpretando e recriando o mundo de muitas e diferentes maneiras" (JOBIM E SOUZA, 2002, p. 77). Conforme analisamos a seguir, muitos memes podem se constituir enquanto estratégias subversivas de normas regulatórias responsáveis pela desqualificação de corpos, gêneros e sexualidades, evidenciando a criatividade e o humor enquanto aspectos que favorecem a contestação das normas e convenções culturais.

3. Práticas de resistência e subversão mediadas por memes: corpo, gênero e sexualidade em debate

Partimos das contribuições foucaultianas e reconhecemos que a liberdade existe onde existe poder (FOUCAULT, 2004). As (cishetero)normas que 


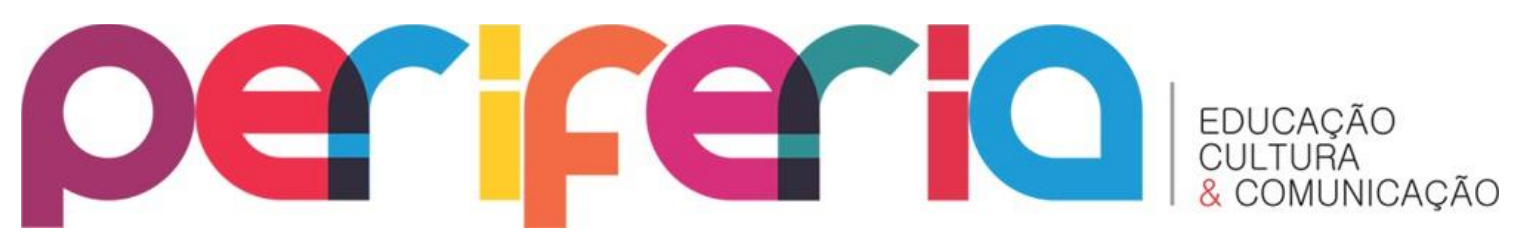

ISSN:1984-9540

DOI: 10.12957/periferia.2019.36180

regulam/governam corpos, gêneros e sexualidades necessitam de constante repetição para se atualizarem, uma vez que "a (hetero)sexualidade, longe de surgir espontaneamente de cada corpo recém-nascido, deve se reinscrever ou se reinstruir através de operações constantes de repetição e de recitação dos códigos (masculino e feminino) socialmente investidos como naturais" (PRECIADO, 2014, p. 26, grifo nosso). Dessa forma, a partir das diversas brechas que se abrem cotidianamente temos a oportunidade criar estratégias de resistência com o objetivo de colocar em suspensão as normas vigentes, desnaturalizando práticas historicamente tidas como "naturais". Algumas dessas estratégias incluem a confecção de memes por internautas de todos os cantos do globo, cuja criatividade e anseio político por mudanças através do questionamento do tempo presente são motivadores para que essas informações digitais sejam produzidas e compartilhadas através de páginas do Facebook e de outras redes sociais.

0 memes discutidos nesta seção do texto colocam em debate "o indivíduo/corpo 'planejado', desenhado, calculado, medido, sujeito a prescrição, tutela, correções, adaptações" (POCAHY, 2011). A análise interpretativa realizada sobre esses memes não se esgota aqui, até porque acreditamos no quanto as imagens são capazes de "falar por si" e o quanto elas são potentes na produção de sentidos de quem as lê. A seguir discutimos alguns memes retirados das páginas "Cartazes \& Tirinhas LGBT" (aproximadamente 700 mil seguidoras/es), "Cartazes \& Tirinhas LGBT - Reserva" (aproximadamente 20 mil seguidoras/es), "Desanimado" (aproximadamente 75 mil seguidoras/es) e "que me transborde" (mais de 3 milhões de seguidoras/es). A escolha desses memes ocorreu devido à popularização das comunidades no Facebook nas quais essas imagens foram compartilhadas, além do fato de que tais imagens promovem reflexões sociais ligadas aos corpos, gêneros e sexualidades, com ênfase na crítica à normatização da vida através do questionamento ao patriarcado, machismo, sexismo, misoginia. 


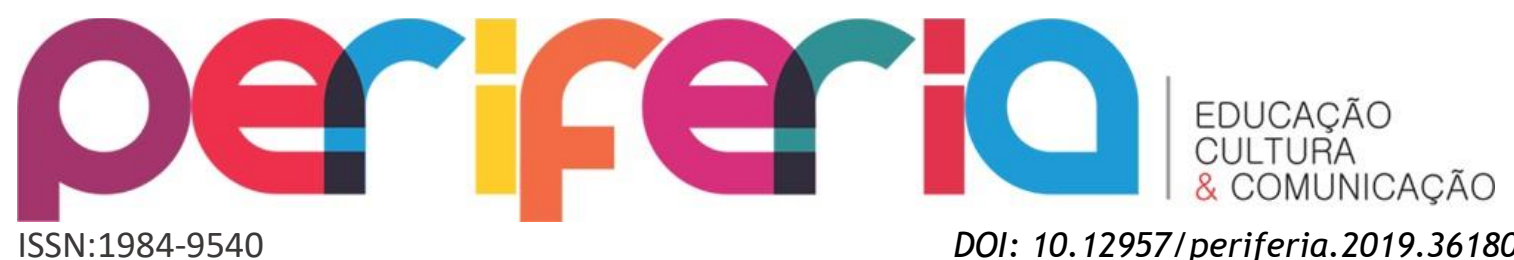

DOI: $10.12957 /$ periferia.2019.36180

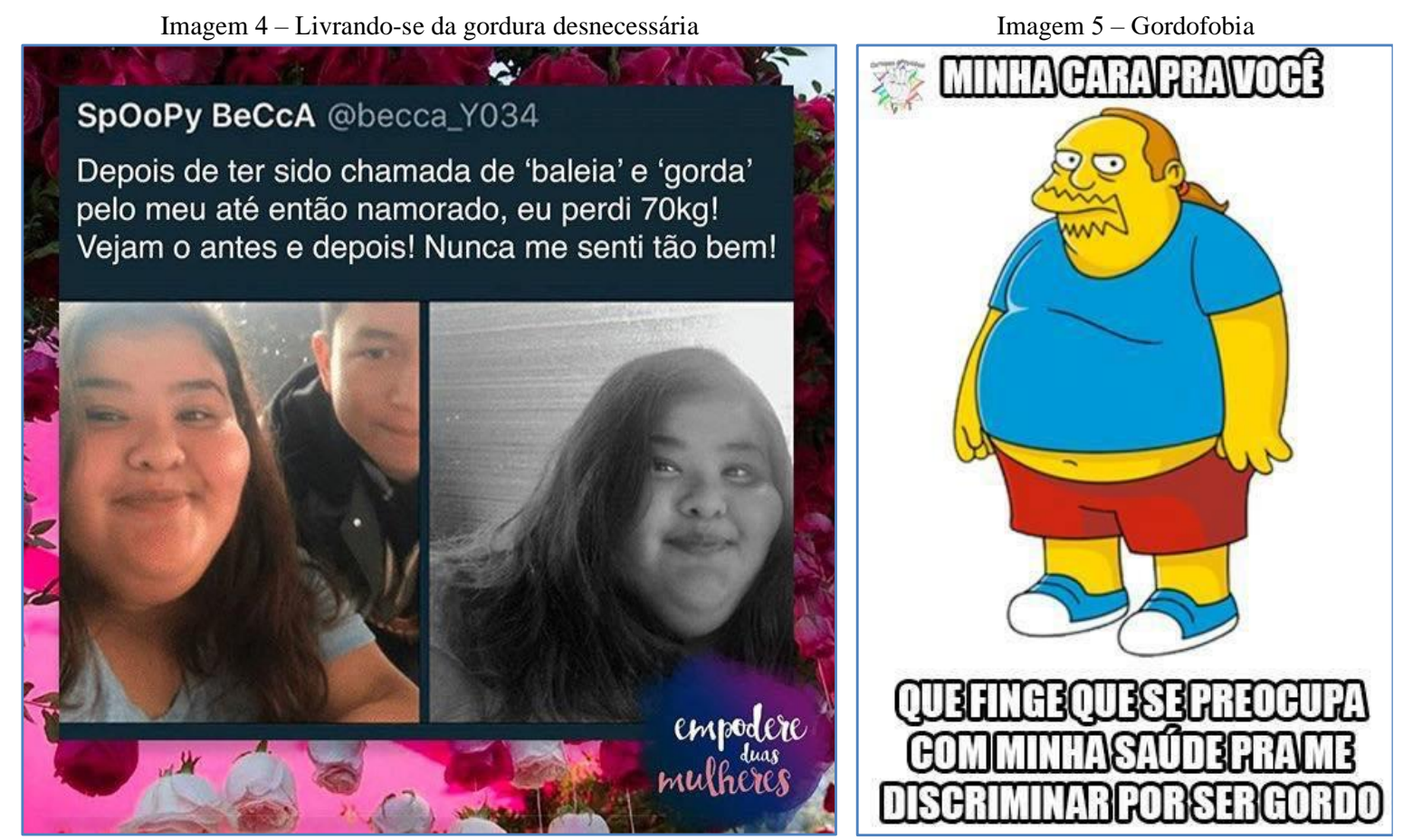

Fonte da imagem 4: página do Facebook "que me transborde" / <goo.gl/Sb7YZ4>

Fonte da imagem 5: página do Facebook “Cartazes \& Tirinhas LGBT - Reserva” / <goo.gl/ja82nj>

Os movimentos sociais em rede no Brasil situam-se num contexto político complexo, repleto de retrocessos sociais que vêm mobilizando pessoas de diversas localidades do país a se engajarem na luta contra as injustiças sociais ${ }^{10}$. Não existe uma "causa única" de luta através das redes sociais, no entanto, precisamos concordar com Castells (2013, p. 8), para quem argumenta que os movimentos em rede são motivados pela “humilhação provocada pelo cinismo e pela arrogância das pessoas no poder, seja ele financeiro, político ou cultural, que uniu aqueles que transformaram medo em indignação, e indignação em esperança de uma humanidade melhor”. Inspirando-nos em Foucault, acreditamos que esses movimentos sociais agem diante de uma determinada correlação de forças, uma determinada forma de governamentalidade que é, constantemente, colocada em questão e disputa. Parece-nos importante uma reflexão sobre 0 processo de transformação/questionamento da atual conjuntura sócio-política através de imagens que são produzidas e colocadas em movimento/circulação. Essas imagens-

\footnotetext{
${ }^{10}$ Foge da proposta deste texto discutir essa complexa conjuntura política no contexto brasileiro, principalmente a partir do Golpe de Estado de 2016 que culminou na retirada de Dilma Rousseff da presidência do país.
} 


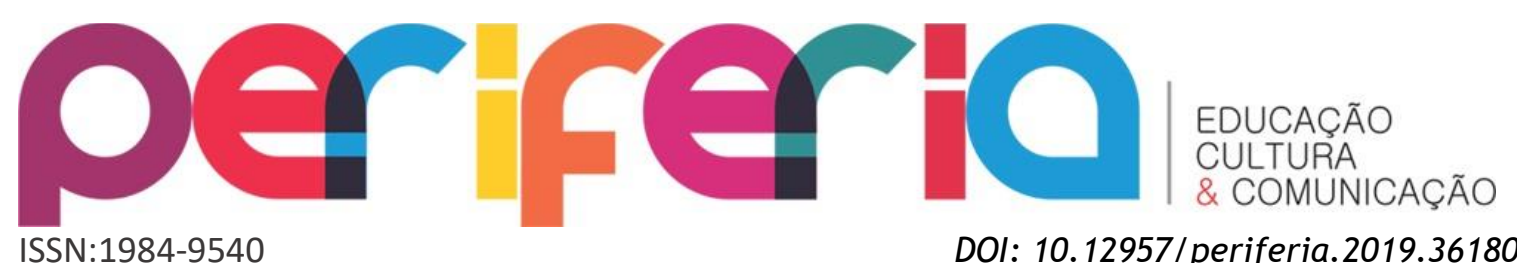

ideias, ao serem difundidas na internet, convidam usuárias/os a questionar regimes de verdade que, historicamente, vêm desqualificando modos de ser/estar no mundo.

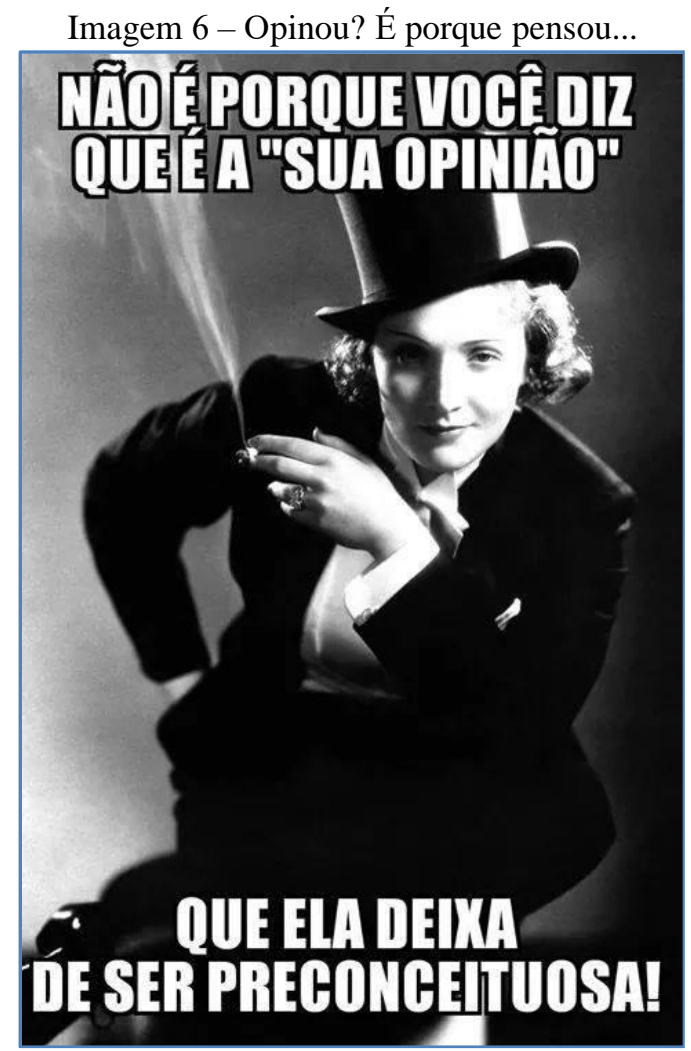

Fonte da imagem 6: página do Facebook "Cartazes \& Tirinhas LGBT" / <goo.gl/NSAMjX>

A liberação da palavra, ou seja, a possibilidade técnica da rede que possibilita a produção e o compartilhamento de informações entre usuárias/os (LEMOS, 2010) evidencia o quanto os memes nos fazem (re)lembrar diariamente a potência das micropolíticas cotidianas mediadas pelo digital em rede. Cabe um olhar sobre a “mobilização política que nos conduz à possibilidade de circulação das posições sobre o discurso das normas de gênero e do exercício da sexualidade, como possibilidades heterogêneas, não naturais e tampouco culturalmente universais" (POCAHY, 2011, p. 27). Dito isso, que possamos aprender-ensinar com os memes as possibilidades de (re)criação engendradas pelo digital em rede para desarmar discursos preconceituosos e discriminatórios que desqualificam os grupos de sujeitos que constituem as chamadas "minorias" sexuais, de gênero e étnico-raciais.

0 enfrentamento às (cishetero)normas regulatórias vem ocorrendo através de intensos embates/discussões que se difundem/viralizam pela internet. Os discursos 


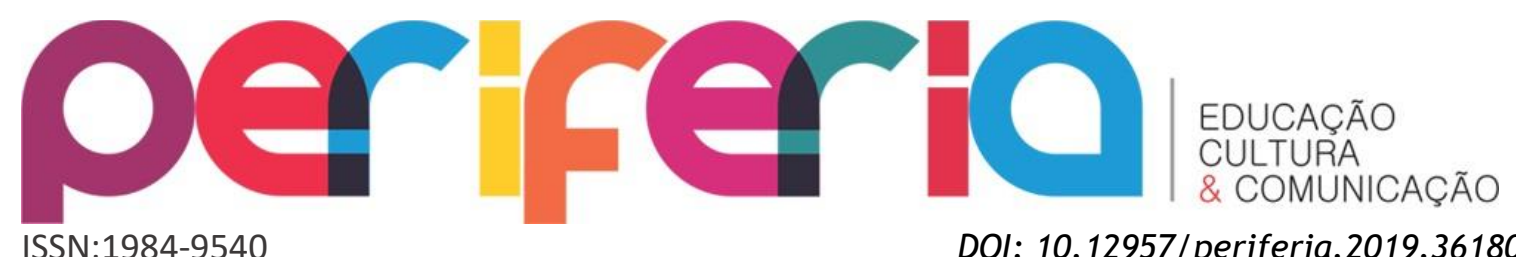

de ódio que se propagam pelo intenso compartilhamento de ideias que defendem o aniquilamento/silenciamento de determinados grupos sociais não permanecem livres para reinarem supremos, pois se deparam com movimentos de resistência que lutam a favor de novas estéticas de existência. Os regimes de verdade colocam em funcionamento discursos normativos "que se organizam através da gestão da vida, controle, 'deciframento', incitação do corpo, organização espacial e institucional, toma particularmente a sexualidade como dispositivo eficaz nos jogos de prescrição e de controle" (POCAHY, 2012b, p. 52). Questionar regimes de verdade que regulam/governam corpos, gêneros e sexualidades vêm sendo o papel de muitos memes, elaborados com a intenção de alertar as/os usuárias/os das inúmeras situações cotidianas que se constituem enquanto graves problemas sociais (homofobia, racismo, misoginia, para citar alguns), não só no Brasil.
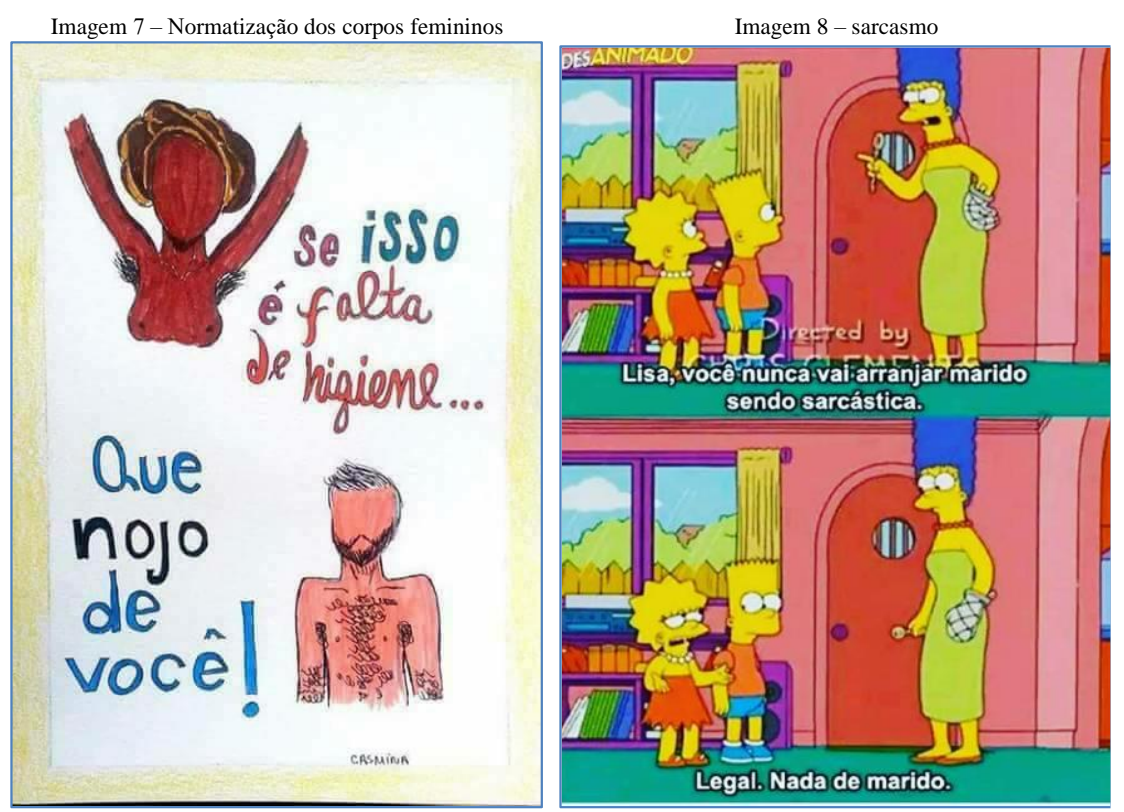

Fonte da imagem 7: página do Facebook "Cartazes \& Tirinhas LGBT - Reserva" / <goo.gl/zNATCS> Fonte da imagem 8: página do Facebook "Desanimado" / <https://www.facebook.com/des4nimado/>

No que se refere à representação e a forma como ela funciona em relação à humanização e à desumanização, Butler (2011, p. 27-28) destaca que "há imagens triunfalistas que nos dão a ideia do humano com que devemos nos identificar, como por exemplo o herói patriótico que expande as fronteiras de nosso ego euforicamente 


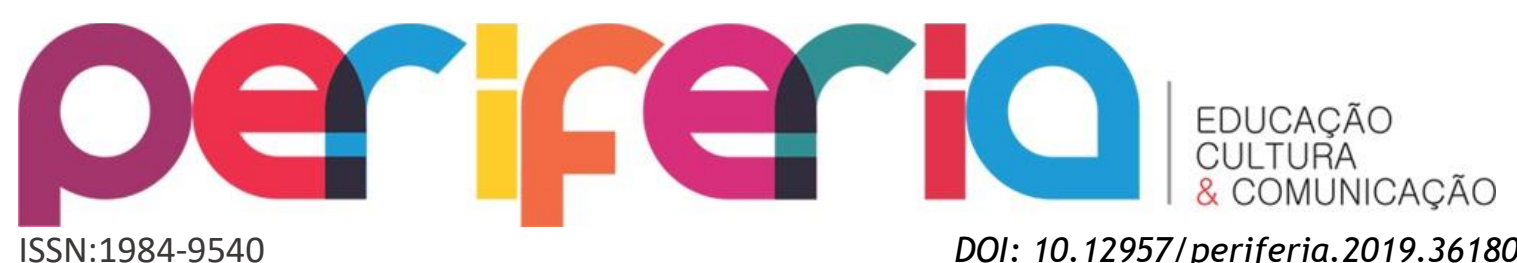

até que se encontre com aquela da própria nação". Frente aos dizeres de Butler, cabe reiterar no contexto deste trabalho que nem todas as imagens-ideias que circulam amplamente-livremente através das redes sociais online vão ao encontro de uma perspectiva "humanizadora", por isso a necessidade encontrada por tantas/os usuárias/os de (re)criar memes capazes de nos inspirar a refletir sobre o tempo presente através da criação de estratégias de subversão e resistência mais “humanizadoras”. Que essas estratégias imagéticas possam denunciar os discursos de ódio responsáveis pelo esfacelamento e esvaziamento de nossa humanidade ao naturalizar a ideia de que nem todo corpo importa e nem toda "morte [é] passível de ser lamentada” (BUTLER, 2011, p. 28).

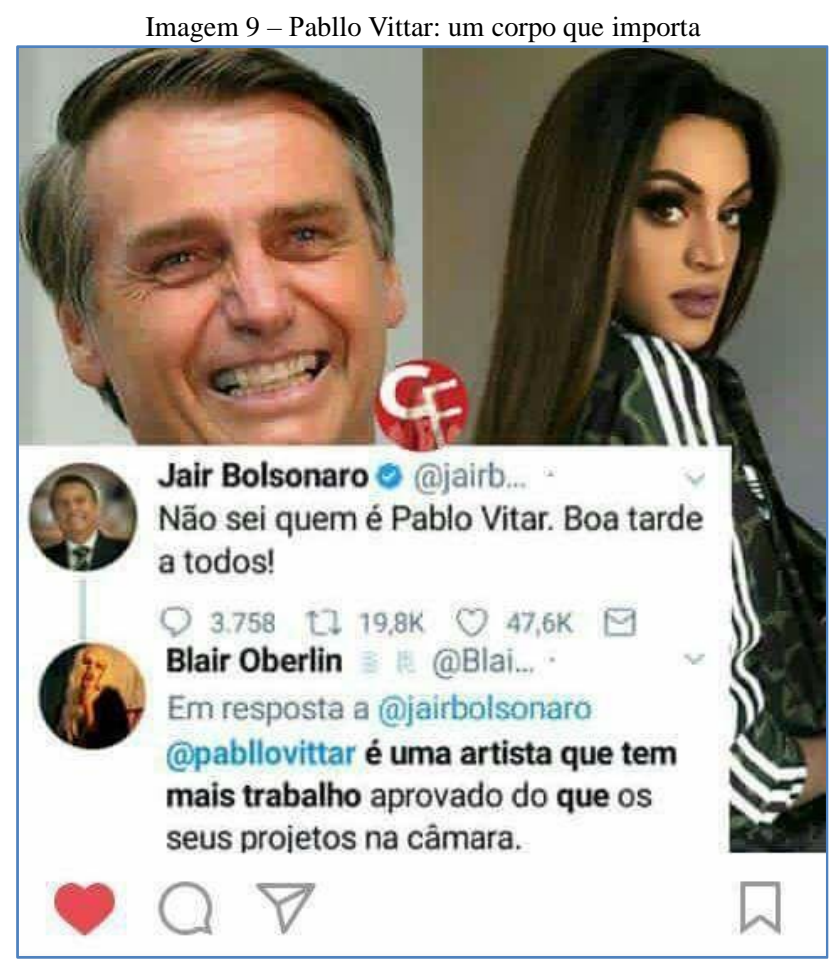

Fonte da imagem 9: página do Facebook “Cartazes \& Tirinhas LGBT" / <goo.gl/YPgKFM>

Os memes têm nos sugerido que é possível "abrir brechas para novos planos de experimentação e produção de subjetividade que tem paixão pelo devir e não temem o caos e aquilo que é estranho" (COUTO JUNIOR; OSWALD; POCAHY, 2018, p. 136), especialmente quando eles denunciam os discursos de ódio e as "personagens" da vida cotidiana que colocam em funcionamento o ato irresponsável de hierarquizar/desqualificar grupos de sujeitos. Que o regime (cis)heterocentrado 


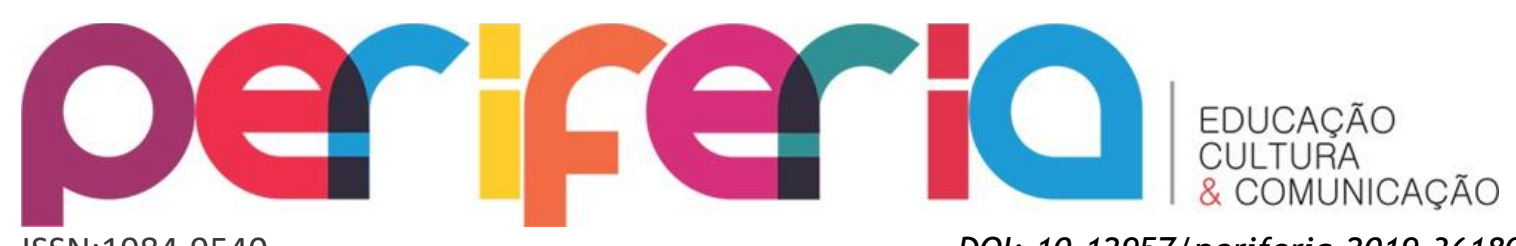

ISSN:1984-9540

DOI: $10.12957 /$ periferia.2019.36180

possa ser desestabilizado pelas imagens irônicas, sarcásticas e cômicas dos memes através do questionamento das premissas regulatórias que fundamentam/atualizam o patriarcado, machismo, racismo e a misoginia na cultura nacional. Nesse sentido, acompanhamos com entusiasmo a profusão e potência dos memes para subverter as dinâmicas sociais, fomentando amplas e criativas práticas educativas mediadas pelo digital em rede que formam e fazem circular noções mesmas de rede e de autoria (em/na/ com rede) .

4. 0 que podemos aprender-ensinar com os memes? Algumas palavras inconclusivas

Acompanhar a produção e o compartilhamento de memes na internet significa acompanhar alguns fluxos das tramas discursivas da vida online envolvendo tópicos variados. Ao retratar momentos cotidianos de vidas/personagens que representam as chamadas "minorias" sexuais, de gênero e étnico-raciais, os memes apresentados neste texto possibilitam perceber algumas estratégias de resistência que denunciam o processo de desumanização dos grupos colocados na condição de precariedade/vulnerabilidade. O pensamento de Butler (2011) nos convida a refletir sobre uma quantidade significativa de vidas cuja humanidade são constantemente ameaçadas. Essas vidas, ao ganharem destaque nos processos comunicacionais em/na rede através dos memes, trazem à tona a necessidade de, enquanto educadoras/es, colocarmos em prática uma reflexão atenta sobre o planejamento de estratégias de resistência no enfrentamento à onda conservadora crescente no Brasil e no mundo que busca desqualificar/normatizar corpos, gêneros e sexualidades.

O humor e o caráter irônico dos memes só podem ser analisados tendo em vista a necessidade de situar essas imagens-ideias num determinado tempo e espaço. Conforme nos lembra Fischer (2003, p. 373) a partir do pensamento foucaultiano, palavras e coisas "têm uma relação extremamente complexa, justamente porque são históricas, são construções, interpretações; jamais fogem a relações de poder; palavras e coisas produzem sujeitos, subjetividades, modos de subjetivação". Dessa 


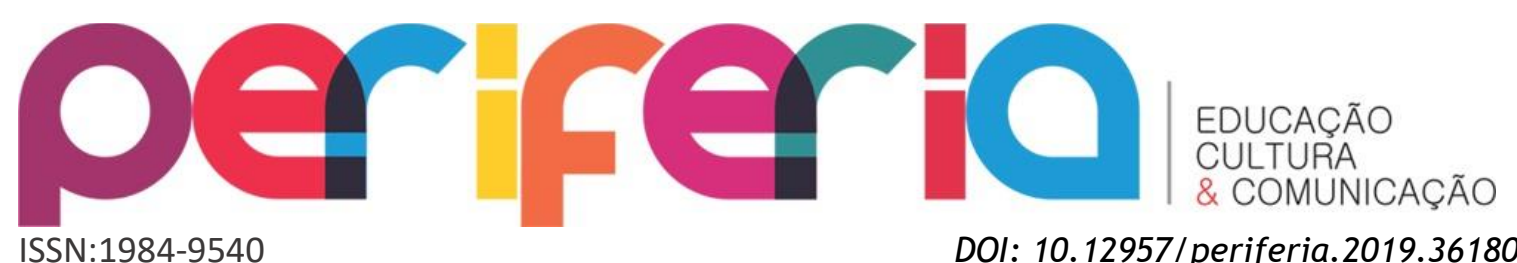

forma, a recente popularização do digital em rede nas interações sociais vêm apontando para o quanto a história mediada por imagens/dizeres digitais que vimos construindo necessitam de maiores reflexões para auxiliar no desafio de (re)pensar a complexa conjuntura sociocultural de um determinado tempo e espaço. Que essa análise do porvir seja capaz de nos fornecer instrumentos analíticos potentes para melhor compreender a proliferação de discursos sintonizados com o regime (cis)heterocentrado e, ao mesmo tempo, seja capaz de mapear/traçar estratégias de enfrentamento e subversão a esse mesmo regime.

\section{Referências}

BUTLER, Judith. Vida precária. Contemporânea - Revista de Sociologia da UFSCar, São Carlos, v.1, n. 1, p. 13-33 jan./jun. 2011. Disponível em:

<http://www.contemporanea.ufscar.br/ojs/index.php/contemporanea/article/vie w/18/3>. Acesso em: 20 jul. 2018.

CASTELLS, Manuel. Redes de indignação e esperança: movimentos sociais na era da internet. Tradução de Carlos Alberto Medeiros. Rio de Janeiro: Zahar, 2013.

COUTO JUNIOR, Dilton Ribeiro. Educação e cibercultura: ensinar e aprender com as imagens digitais nos processos comunicacionais na/da internet. Informática na Educação: teoria \& prática, Porto Alegre, v. 18, n. 1, p. 37-50, jan./jun. 2015. Disponível em:

<http://seer.ufrgs.br/index.php/InfEducTeoriaPratica/article/view/46344/34471>. Acesso em: 20 jul. 2018.

COUTO JUNIOR, Dilton Ribeiro; OSWALD, Maria Luiza Magalhães Bastos.

Cibercultura, juventudes e heteronormatividade: ativismo e resistência no

Facebook. Revista Debates, Porto Alegre, v. 11, n. 2, p. 153-174, maio/ago. 2017. Disponível em:

<http://seer.ufrgs.br/index.php/debates/article/view/74746/43498>. Acesso em: 20 jul. 2018.

COUTO JUNIOR, Dilton Ribeiro; OSWALD, Maria Luiza Magalhães Bastos. "Fico sem nada de interessante pra postar qnd estou recatada!": a relação entre o espaço eletrônico e o espaço físico em conversas mantidas entre jovens no Facebook. In: Edméa Santos; Cristiane Porto. (Orgs.). Facebook e educação: publicar, curtir, compartilhar. Paraíba: EDUEPB, 2014, p. 167-184. Disponível em:

<http://books. scielo.org/id/c3h5q/pdf/porto-9788578792831.pdf>. Acesso em: 20 jul. 2018. 


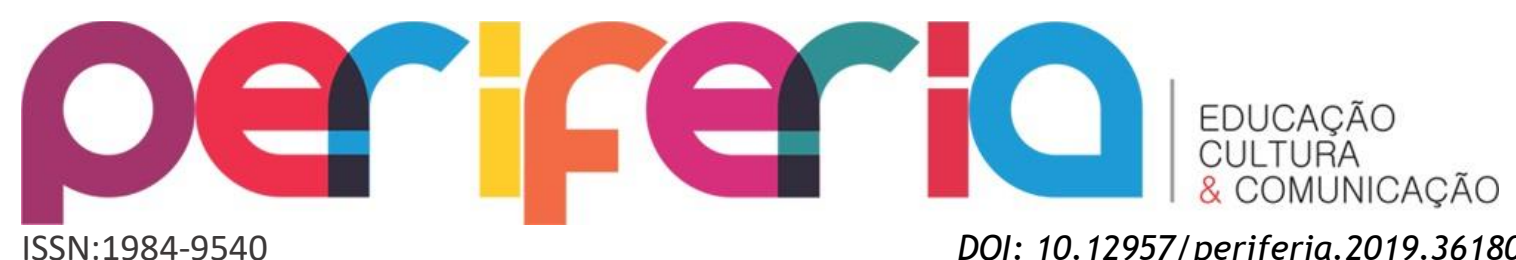

COUTO JUNIOR, Dilton Ribeiro; OSWALD, Maria Luiza Magalhães Bastos; POCAHY, Fernando. Gênero, sexualidade e juventude(s): problematizações sobre heteronormatividade e cotidiano escolar. Civitas, Porto Alegre, v. 18, n. 1, p. 124137, jan./abr. 2018. Disponível em:

<http://www.scielo.br/pdf/civitas/v18n1/1519-6089-civitas-18-01-0124.pdf>. Acesso em: 20 jul. 2018.

COUTO JUNIOR, Dilton Ribeiro; SILVA, João Paulo de Lorena. Corpos transviados ao Sul do Equador: o que Linn da Quebrada tem a nos (des)ensinar? Revista Cocar, Belém, v. 12, n. 23, p. 318-341, jan./jun. 2018. Disponível em:

<https://paginas.uepa.br/seer/index.php/cocar/article/view/1730/949>. Acesso em: 20 jul. 2018.

DIAS, Filipe; TELES, Natalia; KARIME, Pethalla; GROHMANN, Rafael. Memes, uma meta-análise: proposta a um estudo sobre as reflexões acadêmicas do tema. In: CONGRESSO BRASILEIRO DE CIÊNCIAS DA COMUNICAÇÃO, 38., 2015, Anais... Rio de Janeiro, 2015, 15p. Disponível em:

<http: / / portalintercom.org.br/anais/nacional2015/resumos/R10-2479-1.pdf >. Acesso em: 20 jul. 2018.

FISCHER, Rosa Maria Bueno. Foucault revoluciona a pesquisa em educação? Perspectiva, Florianópolis, v. 21, n. 2, p. 371-389, jul./dez. 2003. Disponível em: <https://periodicos.ufsc.br/index.php/perspectiva/article/view/9717/8984>. Acesso em: 20 jul. 2018.

FOUCAULT, Michel. A ética do cuidado de si como prática da liberdade. In: MOTTA, Manoel Barros (Org.) FOUCAULT, Michel. Coleção Ditos \& Escritos V. Ética, sexualidade, política. Tradução de Elisa Monteiro e Inês Autran Dourado Barbosa. Rio de Janeiro: Forense Universitária, 2004, p. 264-287.

JOBIM E SOUZA, Solange. O olho e a câmera: desafios para a educação na época da interatividade virtual. Revista Advir, Rio de Janeiro, n. 15, p. 75-81, set. 2002.

LEMOS, André. Os sentidos da tecnologia: cibercultura e ciberdemocracia. In: LEMOS, André; LÉVY, Pierre. O futuro da internet: em direção a uma ciberdemocracia planetária. São Paulo: Paulus, 2010, p. 21-31.

LEMOS, André; LÉVY, Pierre. O futuro da internet: em direção a uma ciberdemocracia planetária. São Paulo: Paulus, 2010.

OLIVEIRA NETA, Juracy Pinheiro. Por uma tipologia dos memes da internet. Entremeios, Rio de Janeiro, v. 13, n. 2, s/p, jul./dez. 2017. Disponível em: <http://entremeios.com.puc-rio.br/media/Juracy\%200liveira.pdf>. Acesso em: 20 jul. 2018.

PIÑEIRO-OTERO, Teresa; MARTÍNEZ-ROLÁN, Xabier. Los memes en el activismo feminista en la Red. \#ViajoSola como ejemplo de movilización transnacional. 


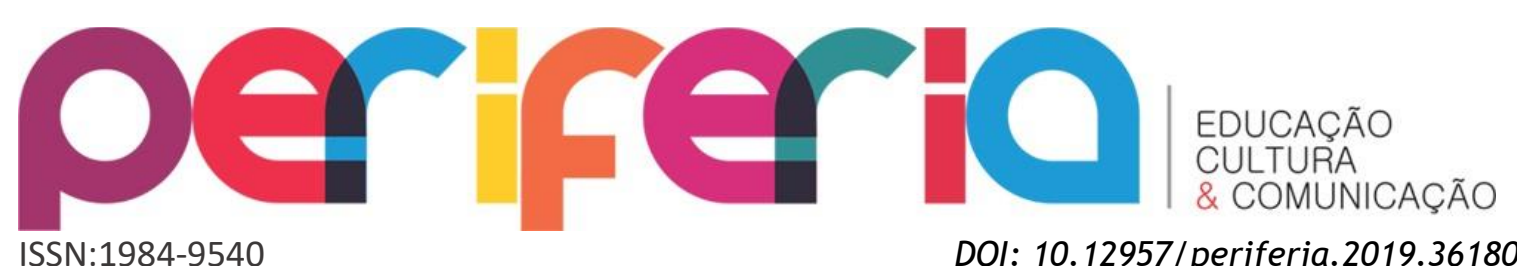

Cuadernos.info, Santiago, n. 39, p. 17-37, 2016. Disponível em:

<http://www.cuadernos.info/index.php/CDI/article/view/cdi.39.1040/pdf_1>.

Acesso em: 20 jul. 2018.

POCAHY, Fernando. Botando corpo, (des)fazendo gênero. Uma ferramenta para a pesquisa-intervenção na educação. Revista Reflexão e Ação, Santa Cruz do Sul, v. 24, n. 1, p. 289-308, jan./abr. 2016. Disponível em:

<https://online.unisc.br/seer/index.php/reflex/article/view/6923/pdf>. Acesso em: 20 jul. 2018.

POCAHY, Fernando. Entre vapores \& vídeos pornôs: dissidências homo/eróticas na trama discursiva do envelhecimento masculino. Revista Estudos Feministas, Florianópolis, v. 20, n. 2, p. 357-376, ago. 2012a. Disponível em:

<http://www.scielo.br/pdf/ref/v20n2/v20n2a02.pdf>. Acesso em: 20 jul. 2018.

POCAHY, Fernando. A velhice como performativo: dissidências (homo)eróticas. Ex aequo, Lisboa, n. 26, p. 43-56, 2012b. Disponível em:

<http: / / www.scielo.mec.pt/pdf/aeq/n26/n26a05.pdf>. Acesso em: 20 jul. 2018.

POCAHY, Fernando. Interseccionalidade e educação: cartografias de uma práticaconceito feminista. Textura, Canoas, v. 13, n. 23, p. 18-30, jan./jun. 2011.

Disponível em:

<http://www.periodicos.ulbra.br/index.php/txra/article/view/984/766>. Acesso em: 20 jul. 2018.

PRECIADO, Paul Beatriz. Manifesto contrassexual: práticas subversivas de identidade sexual. Tradução de Maria Paula Gurgel Ribeiro. São Paulo: n-1 Edições, 2014.

PRETTO, Nelson De Luca. Personagem de 2011: o ativista. In: Reflexões: ativismo, redes sociais e educação. Salvador: EDUFBA, 2013, p. 65-66.

PRETTO, Nelson De Luca; ASSIS, Alessandra. Cultural digital e educação: redes já! In: PRETTO, Nelson De Luca; SILVEIRA, Sérgio Amadeu (Orgs.). Além das redes de colaboração: internet, diversidade cultural e tecnologias do poder. Salvador: EDUFBA, 2008, p. 75-83. Disponível em:

<http://books. scielo.org/id/22qtc/pdf/pretto-9788523208899.pdf>. Acesso em: 20 jul. 2018.

PRIMO, Alex. Interações mediadas e remediadas: controvérsias entre as utopias da cibercultura e a grande indústria midiática. In: PRIMO, Alex (Org.). Interações em rede. Porto Alegre: Editora Sulina, 2013, p. 13-32.

RECUERO, Raquel. Atos de ameaça à face e à conversação em redes sociais da internet. In: PRIMO, Alex (Org.). Interações em rede. Porto Alegre: Editora Sulina, 2013, p. 51-69. 


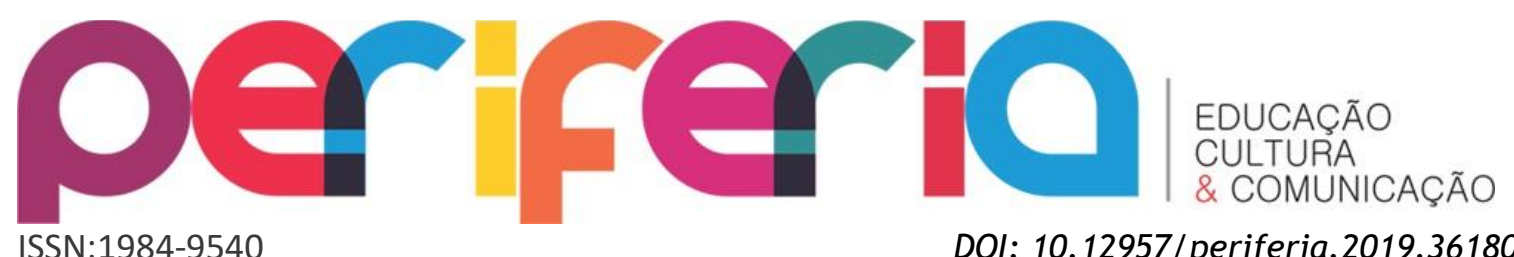

SANTAELLA, Lucia. Intersubjetividade nas redes digitais: repercussões na educação. In: PRIMO, Alex. (Org.). Interações em rede. Porto Alegre: Editora Sulina, 2013, p. 33-47.

SANTOS, Edméa; COLACIQUE, Raquel; CARVALHO, Felipe da Silva Ponte de. A autoria visual na internet: o que dizem os memes? Quaestio, Sorocaba, v. 18, n. 1, p. 135-157, maio 2016. Disponível em:

<http://periodicos.uniso.br/ojs/index.php/quaestio/article/view/2570/2168>. Acesso em: 20 jul. 2018.

SANTOS, Edméa; CARVALHO, Felipe da Silva Ponte de. Autorais partilhadas na interface cidade-redes digitais. Interfaces Científicas - Educação, Aracaju, v. 6, n. 3, p. 29-40, jun. 2018. Disponível em:

<https://periodicos.set.edu.br/index.php/educacao/article/view/5317/2846>. Acesso em: 20 jul. 2018.

SILVA, Adelino; TOMÉ, Rafael; SILVA, Fábio. "Viu Nina?”: o uso de memes e a criação publicitária. Revista Temática, João Pessoa, v. 9, n. 5 , p. 1-14, maio 2013. Disponível em:

<http://periodicos.ufpb.br/index.php/tematica/article/viewFile/21884/12042>. Acesso em: 20 jul. 2018.

TORRES, Ton. O fenômeno dos memes. Ciência e Cultura, São Paulo, v. 68, n. 3, p. 60-61, set. 2016. Disponível em:

<http: //cienciaecultura.bvs.br/pdf/cic/v68n3/v68n3a18.pdf>. Acesso em: 20 jul. 2018.

VOLCAN, Taiane de Oliveira. Comunicação mediada por humor: a legitimação do discurso humorístico pela página Notícias do Senado no Facebook. Linguagem \& Ensino, Pelotas, v. 17, n. 3, p. 627-646, set./dez. 2014. Disponível em:

<http://www.rle.ucpel.tche.br/index.php/rle/article/view/1142/804>. Acesso em: 20 jul. 2018. 